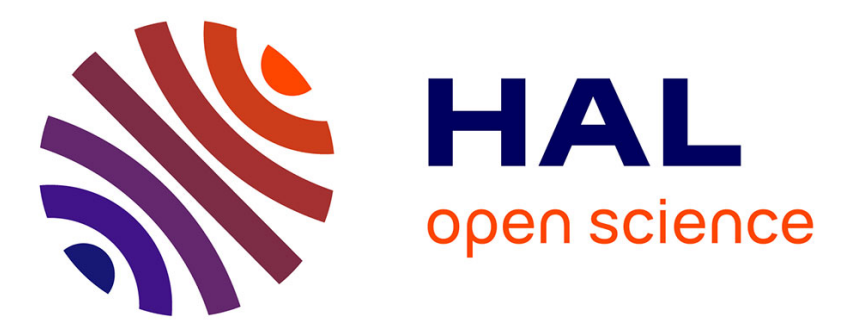

\title{
Straightforward chemo-enzymatic synthesis of new aminocyclitols, analogues of valiolamine and their evaluation as glycosidase inhibitors.
}

\author{
Lahssen El Blidi, Mustapha Ahbala, Jean Bolte, Marielle Lemaire
}

\section{To cite this version:}

Lahssen El Blidi, Mustapha Ahbala, Jean Bolte, Marielle Lemaire. Straightforward chemo-enzymatic synthesis of new aminocyclitols, analogues of valiolamine and their evaluation as glycosidase inhibitors.. Tetrahedron: Asymmetry, 2006, 17, pp.2684-2688. 10.1016/j.tetasy.2006.09.10 . hal-00118415

\author{
HAL Id: hal-00118415 \\ https://hal.science/hal-00118415
}

Submitted on 26 Feb 2007

HAL is a multi-disciplinary open access archive for the deposit and dissemination of scientific research documents, whether they are published or not. The documents may come from teaching and research institutions in France or abroad, or from public or private research centers.
L'archive ouverte pluridisciplinaire HAL, est destinée au dépôt et à la diffusion de documents scientifiques de niveau recherche, publiés ou non, émanant des établissements d'enseignement et de recherche français ou étrangers, des laboratoires publics ou privés. 


\title{
Straightforward chemo-enzymatic synthesis of new aminocyclitols, analogues of valiolamine and their evaluation as glycosidase inhibitors
}

\author{
Lahssen El Blidi, ${ }^{a}$ Mustapha Ahbala, ${ }^{\mathrm{b}}$ Jean Bolte ${ }^{\mathrm{a}}$ and Marielle Lemaire ${ }^{\mathrm{a}, *}$ \\ ${ }^{a}$ Laboratoire SEESIB, UMR 6504 du CNRS, Université Blaise Pascal, 24 av. des Landais, 63177 Aubière cedex, France \\ ${ }^{\mathrm{b}}$ Laboratoire de chimie organique et organométallique, Faculté des sciences, Université Chouab Doukkali, \\ km 1 Route Ben Mâchou BP 2400, El Jadida, Morocco \\ Received 30 August 2006; accepted 13 September 2006 \\ Available online 17 October 2006
}

\begin{abstract}
An efficient fructose-1,6-bisphosphate aldolase mediated synthesis of new aminocyclitol analogues of valiolamine is described. The one-pot process where four stereocentres are created involves the formation of two carbon-carbon bonds. One is catalysed by the aldolase, coupling dihydroxyacetone phosphate to nitrobutyraldehydes. The other is the result of a highly stereoselective intramolecular Henry reaction occurring on the intermediate nitroketones. Depending on the configuration of the hydroxyl which is $\alpha$ to the nitro group, two series of configuration are accessible. The lipase resolution of the nitroalcohol ketal, precursor of the nitroaldehyde, is presented. The inhibition properties of the aminocyclitols obtained after the reduction of the nitro group are evaluated towards five commercial glycosidases.

(c) 2006 Elsevier Ltd. All rights reserved.
\end{abstract}

\section{Introduction}

Glycosidases are enzymes widely distributed in microorganisms, plants and animals. They selectively hydrolyse glycosidic bonds and play important roles in crucial biological pathways such as polysaccharide and glycoconjugate anabolism and catabolism, ${ }^{1}$ cellular recognition ${ }^{2}$ and eukaryotic glycoprotein processing. ${ }^{3}$ Glycosidases are also involved in a variety of metabolic disorders and diseases such as diabetes, viral or bacterial infections and cancer formation. Consequently, their inhibitors have many potential applications ${ }^{4}$ such as antidiabetic, ${ }^{5}$ antiviral (VIH, influenza) ${ }^{6}$ and anticancer ${ }^{7}$ drugs.

The design and synthesis of glycosidase inhibitors are mainly focused on mimicking the transition state (TS) that occurs in an enzymatic glycoside hydrolysis. ${ }^{8}$ A partial positive charge develops at the anomeric carbon and at the endocyclic oxygen (Fig. 1) or at the exocyclic oxygen. Natural aminocyclitols (aminocarbasugars) such as valiolamine 1, validamine 2, valienamine $\mathbf{3}$ (Fig. 1) and their ana-

\footnotetext{
"Corresponding author. Tel.: +3347340 75 84; fax: +3347340 77 17; e-mail: marielle.lemaire@univ-bpclermont.fr
}

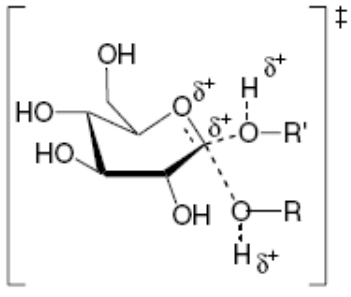<smiles>N[C@H]1C[C@](O)(CO)[C@@H](O)[C@H](O)[C@H]1O</smiles><smiles>N[C@H]1C[C@H](CO)[C@@H](O)[C@H](O)[C@H]1O</smiles><smiles>N[C@H]1C=C(CO)[C@@H](O)[C@H](O)[C@H]1O</smiles>

Figure 1. Transition state model and natural aminocyclitols.

logues can be effective specific inhibitors of glycosidases involved in intestinal degradation of carbohydrates. They are supposed to be partially protonated in the active site at physiological $\mathrm{pH}$, mimicking the TS where the positive charge is located on the exocyclic oxygen. 
As a consequence, a large variety of synthetic approaches have been used to develop this class of compounds, ranging from chemical to enzymatic methods, and employing starting materials ranging essentially from sugars to natural carbocyclic compounds. ${ }^{9}$

Recently we reported the first fructose-1,6-diphosphate aldolase mediated synthesis of aminocyclohexitol $\mathbf{5}$ (Fig. 2) ${ }^{10}$ To access the target compound, our strategy used the condensation of dihydroxyacetonephosphate (DHAP) catalysed by the aldolase (RAMA) on 4-nitroaldehyde 4.

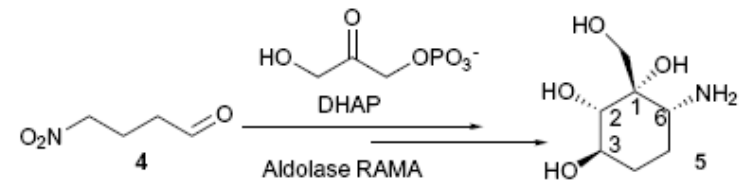

Figure 2. Aldolase-mediated synthesis of aminocyclitol.

The enzyme controlled the configuration of two stereocentres ( 2 and 3 ), forming the $\mathrm{C} 2-\mathrm{C} 3$ bond. The second carbon-carbon bond formation ( 1 and 6 ) was the result of a highly stereoselective intramolecular Henry reaction. In such a process, an enantiomerically pure nitrocyclitol bearing four asymmetric centres was formed. In this report, following this new methodology, we document the synthesis of two nitrocyclitols and their corresponding aminocyclitols with an additional hydroxyl group on C5. The kinetic resolution of the precursor via a lipase is presented. We furthermore report activities of the latter as glycosidase inhibitors.

\section{Results and discussion}

Aldehyde diethyl acetal 6 (Scheme 1) was prepared by ozonolysis of the corresponding alkene ${ }^{11}$ previously ob-

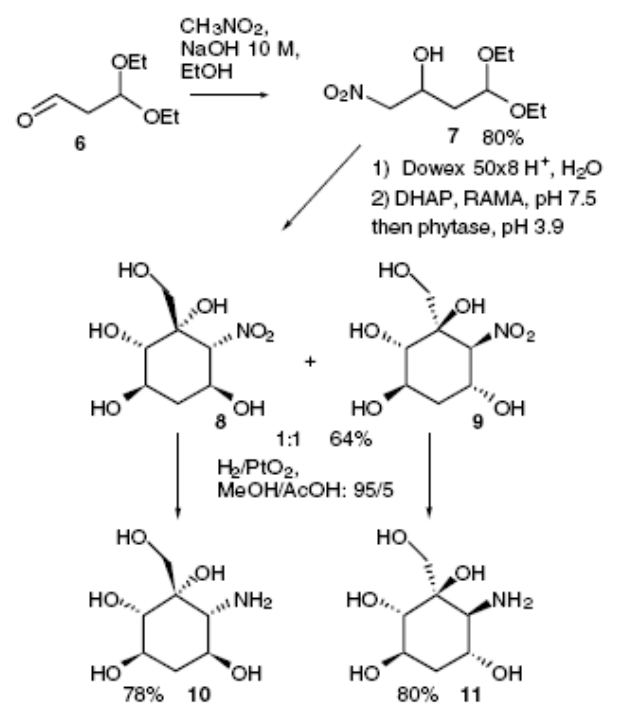

Scheme 1. Synthesis of aminocyclitols. tained using the procedure of Hoaglin et al. ${ }^{12}$ The nitroaldolisation (Henry reaction) between compound 6 and nitromethane gave nitroalcohol 7 in an $80 \%$ yield. This compound has been succinctly described by Yanovskaya et al., ${ }^{13}$ NMR and MS data have not been provided. We fully characterised it to complete its analytical data. Acid-mediated hydrolysis of the ketal furnished an intermediate aldehyde (quantitative from TLC), which was used directly in the aldolisation reaction after $\mathrm{pH}$ adjustment to 7.5. Rabbit muscle aldolase (RAMA) and $\mathrm{DHAP}^{14}$ were added to the reaction mixture. After the DHAP was consumed (checked by enzymatic assay), ${ }^{15}$ the $\mathrm{pH}$ was adjusted to 3.9 and phytase ${ }^{10}$ added to hydrolyse the phosphate group. Two new nitrocyclitols $\mathbf{8}$ and $\mathbf{9}$ were isolated in a $64 \%$ yield (from 7 ) in a 1:1 ratio. They were separated by flash chromatography.

Their absolute configurations (Fig. 3) were determined from NMR data (NOEs and coupling constants), based on the aldolase stereoselectivity, which induces the formation of stereocentre 2 with an $(S)$-configuration. Interestingly, the configuration of the alcohol functionality on 7 influenced nitrocyclisation. When the alcohol was $(S)$, nitrocyclitol $\mathbf{8}$, possessing the same $(1 S, 6 R)$-configurations as compound $\mathbf{5}$ (Fig. 2) was isolated. When the alcohol was $R$, the configuration $1 R, 6 S$ was obtained for compound 9 . We can reasonably assume that the reaction performed in water and at rt was under thermodynamic control. The two nitrocyclitols are the more stable isomers. In both cases, the hydroxymethyl, the nitro and the hydroxyl at position 5 are equatorial. For compound 9, two hydroxyl groups (on carbons 2 and 3 ) are in an axial position. The reduction of the nitro group of $\mathbf{8}$ and $\mathbf{9}$ was then performed over $\mathrm{PtO}_{2}$ under 50 psi of hydrogen. The two aminocyclitols 10 and 11 were isolated with the same $76 \%$ yield.

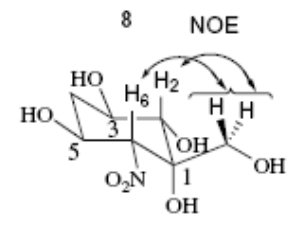

$1 S, 2 S, 3 R, 5 S, 6 R$

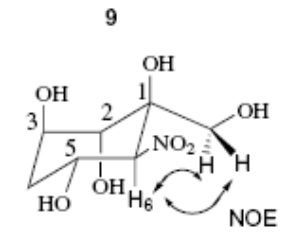

$1 R, 2 S, 3 R, 5 R, 6 S$

Figure 3. NOE's, configurations and major conformations of compounds 8 and 9.

In order to improve yields and avoid the chromatographic separation of nitrocyclitols $\mathbf{8}$ and $\mathbf{9}$, we decided to study the lipase catalysed kinetic resolution of alcohol 7 . We expected to resolve 7 by direct enzymatic acylation of the hydroxy group. All of the results are presented in the table (Table 1).

Three enzymes (entries 1-3) were tested and lipase B from Candida antartica showed the best activity. Alcohol 7 was not a substrate of lipase PS and PC (amano AK and PS, respectively). Different solvents were screened (entries 4 6) and diisopropylether (DIPE) gave the best results. Ester 12 underwent spontaneous elimination, giving a large amount of alkene $\mathbf{1 3}$ (Scheme 2). 
Table 1. Kinetic resolution of 7 at $\mathrm{rt}$

\begin{tabular}{|c|c|c|c|c|c|c|c|c|}
\hline Entry & Enzyme & Molarity & Acyl donor (equiv) & Solvent & $t(\mathrm{~d})$ & $\mathrm{ee}_{\mathrm{s}}{ }^{\mathrm{a}}(\%)$ & $c^{\mathrm{a}}(\%)$ & $E$ \\
\hline 1 & CAL-B ${ }^{b}$ & 0.483 & Vinylacetate (1.2) & TBME & 6 & 55 & 60 & 3.6 \\
\hline 2 & $\mathrm{PSL}^{\mathrm{b}}$ & 0.483 & Vinylacetate (1.2) & TBME & - & - & - & - \\
\hline 3 & $\mathrm{PCL}^{\mathrm{b}}$ & 0.483 & Vinylacetate (1.2) & TBME & - & - & - & - \\
\hline 4 & CAL-B ${ }^{b}$ & 0.483 & Vinylacetate (1.2) & DIPE & 10 & 86 & 55 & 15 \\
\hline 5 & CAL-B ${ }^{b}$ & 0.483 & Vinylacetate & Vinylacetate & 10 & 25 & 30 & - \\
\hline 6 & CAL-B ${ }^{b}$ & 0.483 & Vinylacetate (1.2) & $\mathrm{CH}_{2} \mathrm{Cl}_{2}$ & - & - & - & - \\
\hline 7 & CAL-B ${ }^{b}$ & 0.483 & Succinic anhydride (1.2) & DIPE & - & - & - & - \\
\hline 8 & CAL-B ${ }^{b}$ & 0.483 & Vinylbutyrate (1.2) & DIPE & 7 & 97 & 52 & 75 \\
\hline 9 & CAL-B ${ }^{b}$ & 0.483 & Vinylpalmitate (1.2) & DIPE & 7 & 9 & 24 & - \\
\hline 10 & CAL-B ${ }^{c}$ & 0.120 & Vinylbutyrate (2) & DIPE & 2 & 92 & 50 & 78 \\
\hline
\end{tabular}

${ }^{a}$ Determined by HPLC using 1,3,5-trimethoxybenzene as an internal standard.

${ }^{\mathrm{b}}$ Ratio in weight enzyme:alcohol $(1: 2.5)$

${ }^{c}$ Ratio in weight enzyme:alcohol (1:4).

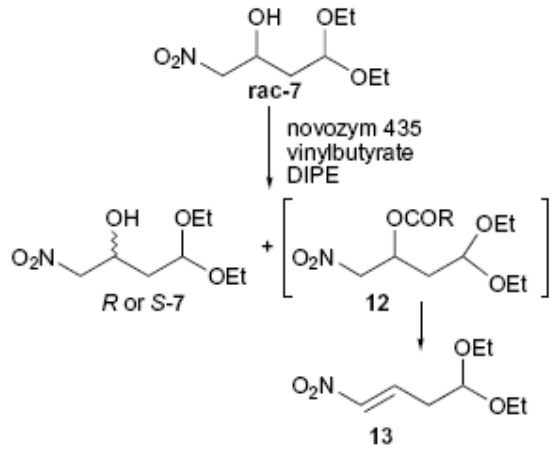

Scheme 2. Lipase resolution of alcohol 7 .

This type of result was also observed by Sheldon et al. with an analogous compound possessing a phenyl group at the same place as our ketal functionality. ${ }^{16}$ Ester 12 was observable by HPLC, while the reaction medium was kept under anhydrous conditions. Even after several attempts to purify it with different workups, we always ended with alkene $\mathbf{1 3}$ as the major product of the reaction. At this point, we turned our attention to the influence of the acyl donor, trying to select a less good leaving group by increasing the alkyl chain length (entries 7-9). No reaction was observed when succinic anhydride was used as the acyl donor. This phenomenon was also observed by Sheldon et al. ${ }^{16}$ with the phenyl analogue cited above. The best result, with a largely improved E, was obtained with vinylbutyrate (entry 8 ). On a preparative scale (entry 10), we recovered alcohol 7 in a $92 \%$ ee and $50 \%$ yield. Finally, we were never able to avoid the formation of alkene 13. From the steric model for the preferentially converted enantiomer of secondary alcohols by CAL-B, we expected to prepare alcohol 7 with an $(R)$-configuration (Scheme 3). This was confirmed by chemical correlation using the aldolase to convert 7 into a nitrocyclitol. Cyclitol 9 was isolated in a 50\% yield (Scheme 3), which confirmed the $R$ configuration for alcohol 7 .

Finally, we comment on the inhibitory activities of the amines prepared in this study against five commercial glycosidases. Amines 10 and 11 were not active against the $\alpha$ glycosidase tested (see Experimental). On the contrary, they moderately and selectively inhibited the $\beta$-glycosidases ( $\beta$-glucosidase and $\beta$-galactosidase). The $K_{\mathrm{i}}$ found for com-

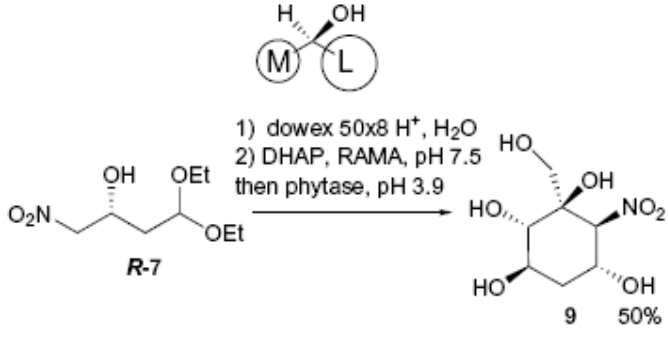

Scheme 3. Steric model for the preferentially converted enantiomer of secondary alcohols by Candida antartica lipase and chemical correlation.

pound 10 were $0.117 \pm 0.03 \mathrm{mM}$ and $1.46 \mathrm{mM}$, and for compound 112.27 and $2.62 \mathrm{mM}$, respectively for $\beta$-glu and $\beta$-gal. Compound 10, mimicking the stereochemistry of glucose more closely was the best inhibitor for $\beta$-glucosidase. More generally, the selectivity for $\beta$-glycosidases could be due to the equatorial position of the amine group. On the contrary in valiolamine, a natural inhibitor of $\alpha$ glucosidases, this amino group is in the axial position.

\section{Conclusions}

As a conclusion, we carried out another efficient synthesis to prepare two new nitrocyclitols and aminocyclitols in a highly stereoselective one-pot/two enzyme process. This illustrates the versatility of our strategy to synthesise aminocyclohexitols in just a few steps, reducing considerably the laborious protection-deprotection steps always found when sugars are used as starting material. Enzymatic resolution of the alcohol precursor showed that the elimination reaction was difficult to avoid, and allowed us to successfully prepare the enantiomerically pure ketal precursor with $R$ configuration. The amines were found to be moderate and selective inhibitors towards $\beta$-glycosidases.

\section{Experimental}

\subsection{General procedures}

All the reagents and solvents were of commercial quality and were purchased from chemical companies. For chro- 
matographic purification, technical grade solvents were distilled prior to use. Merck 60 F254 silica gel TLC plates and Merck 60/230-400 and 60/40-63 mesh silica gel for column chromatography were used. Visualisation of the developed chromatogram was performed by oxidative staining by either $\mathrm{KMnO}_{4}-\mathrm{NaHCO}_{3}$ solution or vanillin solution. Optical rotations, reported in $10^{-1} \mathrm{deg} \mathrm{cm}^{2} \mathrm{~g}^{-1}$, were measured with a Jasco Dip-370 polarimeter. IR spectra were recorded on an FT IR Perkin Elmer 881 spectrophotometer. ${ }^{1} \mathrm{H}$ and ${ }^{13} \mathrm{C}$ NMR spectra were recorded on a Bruker Avance 400 spectrometer in $\mathrm{CDCl}_{3}, \mathrm{D}_{2} \mathrm{O}$ and $\mathrm{CD}_{3} \mathrm{OD}$. $J$ values are given in $\mathrm{Hz}$ and $\delta$ in ppm, referenced to the internal solvent signals for ${ }^{1} \mathrm{H}$ and ${ }^{13} \mathrm{C}$. Fructose-1,6diphosphate aldolase from rabbit muscle (RAMA; EC 4.1.2.13, suspension in ammonium sulfate) and phytase from Aspergillus ficuum (EC 3.1.3.8, crude) were from Sigma. C. Antartica lipase type B (CAL-B, Novozyme 435) was acquired from Sigma. High performance liquid chromatography (HPLC) analyses were carried out in a Waters 590 chromatograph UV detector at $210 \mathrm{~nm}$ using a Daicel Chiracel OD column $(25 \mathrm{~cm} \times 4.6 \mathrm{~mm}$ ID) (hexane/isopropanol 98/2, $0.7 \mathrm{~mL} / \mathrm{min}$ ). New cyclitols synthesised were more or less hygroscopic. Final characterisation of most of these compounds was therefore done by high resolution mass spectra (HRMS), recorded by the Centre Régional de Mesures Physiques de Clermont-Fd, France.

\subsection{Experimental procedures}

4.2.1. 4,4-Diethoxy-1-nitrobutan-2-ol 7. To a solution of aldehyde $\mathbf{6}^{11,12}(2 \mathrm{~g}, 13.7 \mathrm{mmol}, 1$ equiv $)$ in $\mathrm{EtOH}$ $(10 \mathrm{~mL})$ was added nitromethane $(750 \mu \mathrm{L}, 13.7 \mathrm{mmol}$, 1 equiv) followed by $\mathrm{NaOH} 10 \mathrm{~N}(1.37 \mathrm{~mL}, 13.7 \mathrm{mmol}$, 1 equiv). The solution was stirred at $0{ }^{\circ} \mathrm{C}$ for $45 \mathrm{~min}$. The mixture was neutralised with $\mathrm{AcOH}(785 \mu \mathrm{L}, 13.7 \mathrm{mmol}$, 1 equiv) and diluted with $10 \mathrm{~mL}$ water, extracted with $3 \times 100 \mathrm{~mL}$ ether. The combined organic phase was dried over $\mathrm{MgSO}_{4}$, filtered and concentrated in vacuo. The residue was purified by chromatography on silica gel, eluting with cyclohexane/AcOEt (6/4), to afford the target compound as a slightly yellow oil. $R_{\mathrm{f}}=0.42$ cyclohexane/ AcOEt (6/4). ${ }^{1} \mathrm{H}$ NMR (400 MHz, $\mathrm{CDCl}_{3}$ ): $\delta 4.74$ (t, $1 \mathrm{H}$, $J=5 \mathrm{~Hz}) ; 4.57(\mathrm{~m}, 1 \mathrm{H}) ; 4.45(\mathrm{dd}, 2 \mathrm{H}, J=2.3,7 \mathrm{~Hz})$; $3.72(\mathrm{~m}, 2 \mathrm{H}) ; 3.58(\mathrm{~m}, 1 \mathrm{H}) ; 3.55(\mathrm{~m}, 2 \mathrm{H}) ; 1.88(\mathrm{~m}, 2 \mathrm{H})$; $1.22(\mathrm{~m}, 6 \mathrm{H}) .{ }^{13} \mathrm{C} \mathrm{NMR}\left(100 \mathrm{MHz}, \mathrm{CDCl}_{3}\right): \delta 101.3$; $80.4 ; 65.8 ; 62.8 ; 62.5 ; 37.2 ; 15.2$. IR (thin film) $v\left(\mathrm{~cm}^{-1}\right)$ $3435 ; 1550 ; 1376 ; 1125$. SM (IC): $m / z$ 206; 190; 162; 144; 103.

4.2.2. (1S,2S,3R,5S,6R)-1-Hydroxymethyl-6-nitrocyclohexane-1,2,3,5-tetraol 8 and $(1 R, 2 S, 3 R, 5 R, 6 S)$-1-hydroxymethyl-6-nitrocyclohexane-1,2,3,5-tetraol 9. To a solution of 7 (400 mg, $2.65 \mathrm{mmol})$ in $5 \mathrm{~mL}$ water was added a cation exchange resin (Dowex $50 \mathrm{x} 8, \mathrm{H}^{+}$form, $1.5 \mathrm{~g}$ ). The suspension was stirred at $45^{\circ} \mathrm{C}$ for $2.5 \mathrm{~h}$ (quantitative by TLC). The resin was filtered off, the $\mathrm{pH}$ was adjusted to 7.5 with $1 \mathrm{M} \mathrm{NaOH}$. To this solution was added DHAP (3.62 mL, $1.34 \mathrm{mmol}, 1$ equiv) followed by $30 \mathrm{~mL}$ water, and the $\mathrm{pH}$ was adjusted to 7.5 with $1 \mathrm{M} \mathrm{NaOH}$. The mixture was bubbled with Ar and previously centrifuged aldolase $(60 \mathrm{U})$ was added. After stirring $24 \mathrm{~h}$ at $\mathrm{rt}$, the mixture was washed with $3 \times 20 \mathrm{~mL}$ AcOEt. The water phase $\mathrm{pH}$ was adjusted to 3.9 with $1 \mathrm{M} \mathrm{HCl}$ and phytase (92 U) was added. The resulting solution was stirred at $\mathrm{rt}$ for $24 \mathrm{~h}$, then concentrated under vacuum. The residue was purified by chromatography on silica gel, eluting with $\mathrm{CH}_{2} \mathrm{Cl}_{2} / \mathrm{MeOH}(9 / 1$ then $8 / 2)$, to give the target compounds $8(96 \mathrm{mg}, 32 \%)$ and $9(95 \mathrm{mg}, 32 \%)$ as brown solids.

Data for $8, R_{\mathrm{f}}=0.18\left(\mathrm{CH}_{2} \mathrm{Cl}_{2} / \mathrm{MeOH}: 85 / 15\right) . F=136^{\circ} \mathrm{C}$. $[\alpha]_{\mathrm{D}}^{23}=+27 \quad\left(c \quad 2.67, \mathrm{CH}_{3} \mathrm{OH}\right) .{ }^{1} \mathrm{H}$ NMR $(400 \mathrm{MHz}$, $\left.\mathrm{CD}_{3} \mathrm{OD}\right): \delta 4.65(\mathrm{~d}, 1 \mathrm{H}, J=10.2 \mathrm{~Hz}) ; 4.5(\mathrm{ddd}, 1 \mathrm{H}, J=$ $10.2,5.1,12 \mathrm{~Hz}$ ); 3.8 (ddd, $1 \mathrm{H}, J=9.3,12,4.7 \mathrm{~Hz}$ ); 3.78 $(\mathrm{d}, 1 \mathrm{H}, J=11 \mathrm{~Hz}) ; 3.4(\mathrm{~d}, 1 \mathrm{H}, J=9.3 \mathrm{~Hz}) ; 3.25(\mathrm{~d}, 1 \mathrm{H}$, $J=11 \mathrm{~Hz}$ ); 2.27 (ddd, $1 \mathrm{H}, J=4.7,5.1,12 \mathrm{~Hz}$ ); 1.43 (ddd, $1 \mathrm{H}, J=12,12.2,12 \mathrm{~Hz}) .{ }^{13} \mathrm{C}$ NMR $(100 \mathrm{MHz}$, $\left.\mathrm{CD}_{3} \mathrm{OD}\right): \delta 93.3 ; 76.6 ; 75 ; 69 ; 66.7 ; 62 ; 39.1$. IR $(\mathrm{KBr}) v$ $\left(\mathrm{cm}^{-1}\right) \quad 3480 ; 1545 ; 1380 ; 1063$. SM (IC): $\mathrm{m} / z: 246$ $(\mathrm{M}+\mathrm{Na}) ; 228$. Anal. found, C, 37.01; H, 5.88; N, 5.95. $\mathrm{C}_{7} \mathrm{H}_{13} \mathrm{NO}_{7}$ requires $\mathrm{C}, 37.67 ; \mathrm{H}, 5.87 ; \mathrm{N}, 6.28$.

Data for 9, $R_{\mathrm{f}}=0.36\left(\mathrm{CH}_{2} \mathrm{Cl}_{2} / \mathrm{MeOH}: 85 / 15\right) . F=153^{\circ} \mathrm{C}$. $\left.[\alpha]_{\mathrm{D}}^{23}=-33.3(c) 4.25, \mathrm{CH}_{3} \mathrm{OH}\right) .{ }^{1} \mathrm{H}$ NMR $(400 \mathrm{MHz}$, $\left.\mathrm{CD}_{3} \mathrm{OD}\right): \delta 4.67$ (ddd, $\left.1 \mathrm{H}, J=11,4,11 \mathrm{~Hz}\right) ; 4.63(\mathrm{~d}, 1 \mathrm{H}$, $J=11 \mathrm{~Hz}) ; 4.03$ (ddd, $1 \mathrm{H}, J=3,3,3 \mathrm{~Hz}) ; 3.96$ (d, $1 \mathrm{H}$, $J=3 \mathrm{~Hz}) ; 3.77(\mathrm{~d}, 1 \mathrm{H}, J=11.5 \mathrm{~Hz}) ; 3.42(\mathrm{~d}, 1 \mathrm{H}, J=$ $11.5 \mathrm{~Hz}$ ); 2.15 (ddd, $1 \mathrm{H}, J=3,3,13.5 \mathrm{~Hz}$ ); 1.98 (ddd, $1 \mathrm{H}, J=3,11,13.5 \mathrm{~Hz}) .{ }^{13} \mathrm{C}$ NMR $\left(100 \mathrm{MHz}, \mathrm{CD}_{3} \mathrm{OD}\right)$ : $\delta 93.5 ; 78.4 ; 72 ; 70.3 ; 65.4 ; 64.9 ; 36.4$. IR $(\mathrm{KBr}) v\left(\mathrm{~cm}^{-1}\right)$ $3480 ; 1544 ; 1378 ; 1063$. SM (IC): $m / z: 246(\mathrm{M}+\mathrm{Na}) ; 228$. Anal. found, $\mathrm{C}, 37.66 ; \mathrm{H}, 5.87 ; \mathrm{N}, 6.28 . \mathrm{C}_{7} \mathrm{H}_{13} \mathrm{NO}_{7}$ requires C, 37.67; H, 5.87; N, 6.28.

4.2.3. (1S,2S,3R,5S,6R)-6-Amino-1-hydroxymethylcyclohexane-1,2,3,5-tetraol 10. To a solution of nitrocyclitol $8(80 \mathrm{mg}, 0.32 \mathrm{mmol})$ in $\mathrm{MeOH} / \mathrm{AcOH}(95 / 5)(40 \mathrm{~mL})$ was added $\mathrm{PtO}_{2}(20 \mathrm{mg})$. The mixture was submitted to 50 psi of $\mathrm{H}_{2}$ in a Parr apparatus. After stirring for $48 \mathrm{~h}$ at $\mathrm{rt}$, the catalyst was removed by ultrafiltration and washed with $\mathrm{MeOH}$. The filtrate was concentrated under vacuum, and the crude product was purified by cation exchange chromatography (Dowex ${ }^{\circledR} 50 \mathrm{WX} 8,200-400$ mesh, $\mathrm{H}^{+}$form) eluted with $1 \mathrm{M} \mathrm{NH}_{4} \mathrm{OH}$. Compound 10 was obtained as a white solid in $78 \%$ yield $(48 \mathrm{mg}) . R_{\mathrm{f}}=0.22$ $\left(\mathrm{CH}_{2} \mathrm{Cl}_{2} / \mathrm{MeOH} / \mathrm{NH}_{4} \mathrm{OH}: 8 / 1 / 1\right) . F=101^{\circ} \mathrm{C}$. $[\alpha]_{\mathrm{D}}^{23}=-7.9$ (c $\left.1.1, \mathrm{H}_{2} \mathrm{O}\right) .{ }^{1} \mathrm{H}$ NMR $\left(400 \mathrm{MHz}, \mathrm{CD}_{3} \mathrm{OD}\right): \delta 4.65$ (d, $1 \mathrm{H}, J=10.2) ; 4.5$ (ddd, $1 \mathrm{H}, J=10.2,5.1,11.7,5.1 \mathrm{~Hz}$ ); 3.8 (ddd, $1 \mathrm{H}, \quad J=9.3,12,4.7 \mathrm{~Hz}) ; 3.78$ (d, $1 \mathrm{H}$, $J=11 \mathrm{~Hz}) ; 3.4(\mathrm{~d}, 1 \mathrm{H}, J=9.4) ; 3.25(\mathrm{~d}, 1 \mathrm{H}, J=11)$; 2.27 (ddd, $1 \mathrm{H}, J=4.7,5.1,12 \mathrm{~Hz}$ ); 1.43 (ddd, $1 \mathrm{H}$, $J=12,12.2,12 \mathrm{~Hz}) .{ }^{13} \mathrm{C}$ NMR $\left(100 \mathrm{MHz}, \mathrm{CD}_{3} \mathrm{OD}\right): \delta$ $74.4 ; 70.1 ; 69.9 ; 65.7 ; 63.6 ; 57.7 ; 33.9$. IR $(\mathrm{KBr}) v\left(\mathrm{~cm}^{-1}\right)$ $3414 ; 1110$. SM (IC): $\mathrm{m} / \mathrm{z}: 193$.

4.2.4. (1R,2S,3R,5R,6S)-6-Amino-1-hydroxymethylcyclohexane-1,2,3,5-tetraol 11. Compound 11 was isolated as a white solid following the same protocol as described above, in $80 \%$ yield $(49 \mathrm{mg}) . R_{\mathrm{f}}=0.32\left(\mathrm{CH}_{2} \mathrm{Cl}_{2} / \mathrm{MeOH} /\right.$ $\left.\mathrm{NH}_{4} \mathrm{OH}: 8 / 1 / 1\right) . F=76^{\circ} \mathrm{C} .[\alpha]_{\mathrm{D}}^{23}=+6.6\left(c 1.2, \mathrm{H}_{2} \mathrm{O}\right) .{ }^{1} \mathrm{H}$ NMR $\left(400 \mathrm{MHz}, \mathrm{CD}_{3} \mathrm{OD}\right): \delta 4.00$ (ddd, $1 \mathrm{H}, J=3,3$, $3 \mathrm{~Hz}$ ); 3.92 (ddd, $1 \mathrm{H}, J=11,4,11 \mathrm{~Hz}) ; 3.75(\mathrm{~d}, 1 \mathrm{H}$, $J=3 \mathrm{~Hz}) ; 3.73(\mathrm{~d}, 1 \mathrm{H}, J=11.5 \mathrm{~Hz}) ; 3.62(\mathrm{~d}, 1 \mathrm{H}, J=$ $11.5 \mathrm{~Hz}) ; 3.16(\mathrm{~d}, 1 \mathrm{H}, J=10 \mathrm{~Hz}) ; 2.07(\mathrm{ddd}, 1 \mathrm{H}, J=3$, $3,13.5 \mathrm{~Hz}$ ); 1.83 (ddd, $1 \mathrm{H}, J=3,11,13.5 \mathrm{~Hz}$ ). ${ }^{13} \mathrm{C}$ NMR 
$\left(100 \mathrm{MHz}, \quad \mathrm{CD}_{3} \mathrm{OD}\right): \delta \quad 74.8 \quad 70.1 ; \quad 69.9 ; \quad 65.5 ; \quad 64.2 ;$ 57.3; 33.9. IR (KBr) $v\left(\mathrm{~cm}^{-1}\right) 3414 ; 1110$. SM (IC): $m / z$ : 193.

\subsubsection{Lipase kinetic resolution of 7 by transesterification}

4.2.5.1. General. In a typical procedure for analytical study, the corresponding acyl donor was added to a suspension of 7 and CAL-B in DIPE (or other solvent cited in the table) and the mixture was shaken at RT following the progress of the reaction by chiral HPLC (Chiracel OD) and 1,3,5-trimethoxybenzene as an internal standard. After removal of the enzyme by filtration and evaporation of the solvent, the residue was purified by flash chromatography (cyclohexane/AcOEt $(8 / 2)$ ) to give alcohol $(R)-7$ and alkene 13.

4.2.5.2. For preparative scale. (R)-4,4-Diethoxy-1nitrobutan-2-ol 7. In the procedure described above, racemic alcohol $7(0.5 \mathrm{~g}, 2.41 \mathrm{mmol}, 1$ equiv) and CAL-B $(2 \mathrm{~g})$ in DIPE $(20 \mathrm{~mL})$ and vinylbutyrate $(630 \mu \mathrm{L}$, $4.96 \mathrm{mmol}, 2.06$ equiv) as acyl donor were used. The alcohol $(R)-7(460 \mathrm{mg})$ was obtained in a $49 \%$ yield, and $92 \%$ ee after a flash chromatography purification. $[\alpha]_{\mathrm{D}}^{23}=-10.4(c$ $1.22, \mathrm{CHCl}_{3}$ ). Spectral data were identical to the racemic sample.

4,4-Diethoxy-1-nitrobut-1-ene 13. In the above procedure, alkene $13(190 \mathrm{mg})$ was obtained in a $41 \%$ yield.

$R_{\mathrm{f}}=0.54$ (cyclohexane/AcOEt: 7/3). ${ }^{1} \mathrm{H}$ NMR (400 MHz, $\left.\mathrm{CD}_{3} \mathrm{OD}\right): \delta 7.17(\mathrm{~m}, 1 \mathrm{H}) ; 6.96(\mathrm{~d} ; 1 \mathrm{H}, J=14 \mathrm{~Hz}) ; 4.53$ (t, $2 \mathrm{H}, J=5.3 \mathrm{~Hz}) ; 3.62(\mathrm{qd}, 2 \mathrm{H}, J=7.1 \mathrm{~Hz}) ; 3.43(\mathrm{qd}$, $2 \mathrm{H}, J=7.1 \mathrm{~Hz}) ; 2.51(\mathrm{dd}, 2 \mathrm{H}, J=5.3,5.4 \mathrm{~Hz}) ; 1.16(\mathrm{t}$, $6 \mathrm{H}, J=7.2 \mathrm{~Hz}) .{ }^{13} \mathrm{C}$ NMR $\left(100 \mathrm{MHz}, \mathrm{CD}_{3} \mathrm{OD}\right): \delta 141.1$; $137.4 ; 100.5 ; 62.0 ; 33.2 ; 15.2$. IR (thin film) $v\left(\mathrm{~cm}^{-1}\right)$ $1652 ; 1528 ; 1349 ; 1122 ; 1061$. SM (IC): $m / z: 189$.

4.2.6. Chemical correlation. Nitrocyclitol 9 was obtained from $(R)-7$ following the protocol described above (97 $\mathrm{mg}, 51 \%$ ) as a brown solid.

\subsection{Inhibition studies}

$\alpha$-glucosidase from rice, $\alpha$-glucosidase from baker's yeast, $\beta$-glucosidase from almond, $\alpha$-galactosidase from green coffee beans, $\beta$-galactosidase from Aspergillus oryzae, $\alpha$ mannosidase from jack beans and all substrates (4- or 2nitrophenyl $\alpha$ - or $\beta$-glycopyranosides) were purchased from Sigma. Assays were run at $25^{\circ} \mathrm{C}$ in a phosphate buffer $(25 \mathrm{mM})$ at $\mathrm{pH} 6.8$ using the corresponding 4-nitrophenyl-glycoside in a total volume of $1 \mathrm{~mL}$. The potential inhibitors were tested at a final concentration of $1 \mathrm{mM}$ and the amount of enzyme of each assay was adjusted so that the system would give the initial rate. After two periods ( $5 \mathrm{~min}$ and $30 \mathrm{~min}$ ) of incubation of the enzyme in the presence of the tested molecule, the substrate was added and the optical absorbance was followed at $400 \mathrm{~nm}$. The initial rate was determined, compared to the one obtained without the tested molecule, and the percentage of inhibition was calculated. When the percentage of inhibition was higher than $33 \%$, the $K_{\mathrm{i}}$ was determined according to the Hanes-Woolf method. Four substrate concentrations $(0.04-2.5 \mathrm{mM})$ and four inhibitor concentrations $(0.005-0.8 \mathrm{mM})$ were chosen. The $K_{\mathrm{i}}$ was then calculated from the Michaelis-Menten $\left(K_{\mathrm{M}}\right.$ and four $\left.K_{\mathrm{M}}^{\prime}\right)$ constants obtained in the presence or absence of inhibitor. When the percentage of inhibition was between $33 \%$ and $10 \%$, the $K_{\mathrm{i}}$ was determined with the following equation $K_{\mathrm{i}}=[\mathrm{I}] /\left(K_{\mathrm{M}}^{\prime} / K_{\mathrm{M}}-1\right)$, using only one $K_{\mathrm{M}}^{\prime}$ value.

\section{Acknowledgements}

The authors thank Agence Universitaire de la Francophonie (AUF) for financial support (L. El Blidi grant).

\section{References}

1. (a) Kobata, A. Anal. Biochem. 1979, 100,1-14; (b) Lehmann, J. Carbohydrates: Structure and Biology; G. Thieme, Verlag: New York, 1998; (c) Melendez-Hevia, E.; Waddell, T. G.; Shelton, E. D. Biochem. J. 1993, 295, 477-483.

2. (a) Sharon, N.; Lis, H. Sci. Am. 1993, 268, 82-89; (b) Sharon, N.; Lis, H. Science 1989, 246, 227-234.

3. (a) Kornfeld, R.; Kornfeld, S. Annu. Rev. Biochem. 1976, 45, 217-237; (b) Kang, M. S.; Liu, P. S.; Bernotas, R. C.; Harry, B. S.; Sunkara, P. S. Glycobiology 1995, 5, 147-152; (c) Varki, A., Cummings, R., Esko, J., Freeze, H., Hart, G., Marth, J., Eds.; Cold Spring Harbor Laboratory Press, Woodbury, New York, 1999; (d) Herscovics, A. Biochim. Biophys. Acta 1999, 1473, 96-107.

4. For a review, see: Asano, N. Glycobiology 2003, 13, 93R.

5. Scheen, A. J. Drugs 2003, 63, 933-951.

6. (a) Ratner, L.; Heyden, N. V.; Dedera, D. Virology 1991, 181, 180-192; (b) Mehta, A.; Rudd, P. M.; Block, T. M.; Dwek, R. A. Biochem. Soc. Trans. 1997, 25, 1188-1193.

7. (a) Goss, P. E.; Baker, M. A.; Carver, J. P.; Dennis, J. W. Clin. Cancer Res. 1995, 1, 935-944; (b) Nishimura, Y.; Satoh, T.; Adachi, H.; Kondo, S.; Takeuchi, T.; Azetaka, M.; Fukuyasu, H.; Lizuka, Y. J. Med. Chem. 1997, 40, 26262633.

8. Lillelund, V. H.; Jensen, H. H.; Liang, X.; Bols, M. Chem. Rev. 2002, 102, 515-553.

9. (a) Chen, X.; Fan, Y.; Zheng, Y.; Shen, Y. Chem. Rev. 2003, 103, 1955-1978; (b) Ogawa, S.; Ohishi, Y.; Asada, M.; Tomoda, A.; Takahashi, A.; Ooki, Y.; Mori, M.; Itoh, M.; Korenaga, T. Org. Biomol. Chem. 2004, 3, 884-889; (c) Ogawa, S. In Carbohydrate Mimics; Chapleur, Y., Ed.; WileyVCH: Weinheim, Germany, 1998; pp 88-106.

10. El Blidi, L.; Crestia, D.; Gallienne, E.; Demuynck, C.; Bolte, J.; Lemaire, M. Tetrahedron: Asymmetry 2004, 15, 29512954.

11. Trost, B. M.; Dumas, J.; Villa, M. J. Am. Chem. Soc. 1992, $114,9836-9845$.

12. Hoaglin, R. I.; Kubler, D. G.; Montagna, A. E. J. Am. Chem. Soc $1958,80,5460-5463$

13. Yanovskaya, L. A.; Kucherov, V. F.; Kovalev, B. G. Bull. Acad. Sci. USSR, Div. Chem. Sci. (Engl. Transl.) 1962, 623629.

14. Charmantray, F.; El Blidi, L.; Gefflaut, T.; Hecquet, L.; Bolte, J.; Lemaire, M. J. Org. Chem. 2004, 69, 9310-9313.

15. Bergmeyer, H. U. In Methods in Enzymatic Analysis, 34th ed.; Chemie, 1984; Vol. 11, pp 146-147.

16. Sorgedrager, M. J.; Malpique, R.; van Rantwijk, F.; Sheldon, R. A. Tetrahedron: Asymmetry 2004, 15, 1295-1299. 